\title{
GLOBAL ECONOMIC CRISIS AND STOCK MARKETS EFFICIENCY: EVIDENCE FROM SELECTED AFRICA COUNTRIES
}

\author{
SHERIFFDEEN A. TELLA* \\ Babcock University \\ OLUMUYIWA G. YINUSA** \\ Olabisi Onabanjo University
}

AYINDE TAOFEEK OLUSOLA
Centre for Applied Economics and Policy Studies

\begin{abstract}
This paper attempts to check the efficiency of the stock markets in Africa (using the Cairo, Johannesburg and Lagos stock markets) as an aftermath of the global economic crisis as well as the lag in effect of the crisis on the stock markets. Using summary statistics, tests of stationarity and EGARCH methods, it is found that there has been contagion with some lag period, actually towards the end of the peak of the crisis and that the African stock markets remain inefficient.
\end{abstract}

Key words: global crisis, efficiency, stock market, stationarity, EGARCH. JEL Classification: N70, H21, G14, C32.

\section{KÜRESEL EKONOMIKK KRİZ VE MENKUL KIYMETLER BORSASI VERIMLILIIĞI: SEÇİLMISS AFRIKA ÜLKELERINDEN KANITLAR}

\begin{abstract}
ÖZET
Bu makale, küresel ekonomik krizin hemen sonrasında Afrika'daki menkul kıymetler borsalarının (Kahire, Johannesburg ve Lagos menkul klymetler borsaları verilerine dayanarak) verimliliğini ve bu krizin borsalar üzerindeki gecikmeli etkisini incelemeyi amaçlamaktadır. Özet istatistiksel

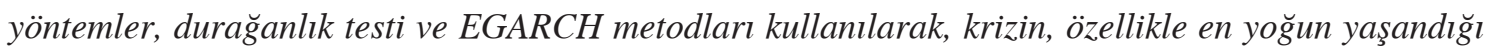
dönemin sonlarına doğru gecikmeli olarak bir ülkeden diğer ülkeye geçtiği ve Afrika menkul klymetler borsalarının verimsiz olmaya devam ettikleri sonuçları bulunmuştur.
\end{abstract}

Anahtar kelimeler: küresel kriz, verimlilik, menkul kıymetler borsası, durağanlık, EGARCH. JEL Sınıflaması : N70, H21, G14, C32.

* Sheriffdeen A. Tella is a Professor in the Department of Economics, Banking and Finance at Babcock University, Ilishan-Remo, Ogun State, Nigeria. E-mail: satellang@yahoo.com.

** Olumuyiwa, G. Yinusa is a lecturer in the Department of Accounting at Olabisi Onabanjo University, Ago-Iwoye, Ogun State, Nigeria. E-mail: ghanniy@yahoo.com.

*** Ayinde Taofeek Olusola is a Junior Research Fellow in the Centre for Applied Economics and Policy Studies, (CEAPEPS), 98, Abeokuta Road, Ijebu-Ode, Ogun State, South-West, Nigeria. E-mail: olusolaat@yahoo.com

Boğaziçi Journal Vol. 25, no. 1 (2011), pp. 139-169. 
The stock market provides the fulcrum for capital market activities and it is often cited as a barometer for business direction. An active stock market may be relied upon to measure changes in the general economic activities using the stock market index (Obadan, 1998). The development of the capital market, and apparently the stock market, provides opportunities for greater funds mobilization, improved efficiency in resource allocation and provision of relevant information for economic activities' appraisal (Inanga and Emenuga, 1997).

Despite the giant strides in investment opportunities taken in the recent past by a host of African countries to leapfrog their various economies towards the path of development through the development of the capital market, some studies on contagion in Africa still suggest that African markets (except the Johannesburg Stock market and probably Egypt) are less fundamentally involved with other emerging markets and by implication, are still fragile and not integrated into the global capital market. The African stock markets are relatively small, with lower and fewer listed companies when compared with other emerging markets. Many African markets have low foreign investment ceilings and most are not included in the International Finance Corporation's Investibles (IFCI) index (Collins and Biekpe, 2004). This implies that there is little or no foreign investment in these markets.

However, Tella (2009) posited that the conclusion drawn by Collins and Biekpe (2004) on African markets is short-lived as indications on local finance markets in Africa, particularly happenings in the Nigerian Stock Market since the first quarter of 2008 and the currency market since the last quarter of the year, have indicated that the local financial market is not insulated from the financial contagion around the world. Particularly, when it was found that there was foreign capital inflow into the Nigerian stock market between 2004 and 2007 during banking consolidation. Table 1 shows that Sub-Saharan Africa has experienced a steady increase in economic globalization in the last four decades, i.e. from an index of 29.83 in 1970-79 to 46.57 in 2000-09. This supports the presumption that African markets are steadily integrating into the world markets.

Table 1

KOF Globalization Index for Sub-Saharan Africa (Average)

\begin{tabular}{lcccc}
\hline & $\mathbf{1 9 7 0 - 7 9}$ & $\mathbf{1 9 8 0 - 8 9}$ & $\mathbf{1 9 9 0 - 9 9}$ & $\mathbf{2 0 0 0 - 0 9}$ \\
\hline Central Africa & 24.07 & 29.11 & 32.09 & 39.93 \\
East Africa & 22.22 & 24.66 & 33.18 & 43.07 \\
South Africa & 48.86 & 51.63 & 54.43 & 59.10 \\
West Africa & 24.16 & 29.25 & 35.84 & 44.16 \\
SSA & 29.83 & 33.66 & 38.88 & 46.57 \\
World & 41.09 & 44.26 & 51.33 & 60.48 \\
\hline
\end{tabular}

Source: konjunkturforschungsstelle (KOF), Swiss Economic Institute Database 2010, ETH, Zurich, Germany.

In his study, Tella (2009) showed that there was co-movement between the Nigerian stock market and the Dow-Jones of the United States. Also, he found that, though there is no long run relationship between the two stock exchanges, the Dow-Jones Granger-cause, that is, has some effect on the Nigerian stock market. Hence, the Nigerian stock market is therefore not totally immune to the vagaries of the world financial crisis given that the Dow-Jones influences many stock exchanges around the world. This agrees with Edwards' (2000) assertion that, in a world of high capital mobility, even small adjustments in international portfolio allocations to emerging economies can result in very 
large savings in capital flows. Sudden reduction in these flows or unanticipated outflow can have serious effects on domestic interest rates and exchange rates, resulting in reducing policy credibility and unleashing a vicious circle.

Therefore, the contending issue in the face of these studies is a question that has been left, at best, controversial in empirical studies: Could African stock markets have been or become efficient in the face of the global economic crisis which generated serious uncertainty and volatility in the stock markets, and were they affected during the crisis? The focus of this study is to investigate the validity of this question.

The concept of efficiency in this case is premised on the Efficient Market Hypothesis (EMH) which suggests that a market is efficient when prices always fully reflect available information. That is, all currently available information is embedded in the current prices (Fama, 1970; Bailey, 2005). The efficiency of stock markets is one of the most controversial and well studied propositions in the literature of the capital market. Even if there have been a number of researches and journal articles, economists have not yet reached a consensus about whether capital markets are efficient or not. The wide range of studies concerning the efficient market hypothesis in the literature provides mixed evidences. The studies such as Sharma and Kennedy (1977), Barua (1980, 1987), Sharma (1983), Ramachandran (1985), Gupta (1985), Srinivasan (1988), Vaidyanathan and Gali(1994) and Prusty (2007) support the weak form efficiency of Indian capital market.

There have been some studies like Kulkarni (1978), Chaudhury (1991), Poshakwale (1996), Pant and Bishnoi (2002), Pandey (2003) and Gupta and Basu (2007), (Mishra, 2009) and (Mishra and Pradhan, 2009) which do not support the existence of weak form efficiency. This disagreement regarding the Efficient Market Hypothesis has generated research interest in this topic. Additionally, the recent market downsizing across the globe has also contributed to it.

The paper adopts a two-prong methodological approach to investigating the subject matter. First, we use unit roots tests and summary statistics to determine the issue of contagion and secondly, we employ GARCH and E-GARCH to investigate volatility and thus efficiency of the markets. These are further espoused in the appropriate sections of the paper.

Apart from this introduction, the rest of the paper is divided into six sections. Section II contains the literature review with sub-sections on issues relating to definitions, conceptual and theoretical considerations of market efficiency, Section III looks into the review of available literature while Section IV focuses on the review of empirical studies and the methodological review. Section V examines the trend of stock market development in Africa prior to and during the global economic crisis, Section VI sets the methodology and analytical framework, Section VII considers the model estimations and discussion of findings while Section VIII which serves as the last section, makes the conclusion and proffers necessary policy suggestions.

\section{LITERATURE REVIEW}

\section{Definitional Issues}

The available theoretical framework revolving around an efficient market hypothesis represents different stages of the development of the concepts and reflects various views of the researchers. In 
the process of development of capital market efficiency into modern form, it is possible to recognize two different approaches. Fama's (1970) approach is referred to as the "empirical" tradition of the Chicago school, which developed earlier formal foundations of EMH (Findlay and Williams, 2000).

The "information" economics approach can be gleaned from the works of Rubinstein (1975), Beaver (1981), and Latham (1986), who introduced alternative definitions. The approach of Fama (1970) concentrated on explaining how the market uses information or establishes prices, whereas the "information economics" school attempted to formalize the EMH considering individual investors and their relation to prices. Beaver (1981) defines market to be efficient with respect to information signal if it generates security prices identical to those that would be generated in a market where each individual investor knows the signal, given that preferences and endowments are identical in both markets. Latham (1986) defines efficiency relative to some information set that, if revealed to all investors, would not change prices and portfolios.

As pointed out by Ball (1994) more formal definitions over Fama's model are of limited use for empirical researches. In the "identical world" where all investors are assumed to possess the available information without cost; however, in the real world it is impossible that all investors could work without cost and also be fully informed about all information (Ball, 1994). Therefore, any test of efficiency has to assume an equilibrium model, which was proposed by the "empirical school." Fama's (1970) definition that in an efficient market, prices "fully reflect" available information was criticized by Leroy (1989) as empty and tautological. He argues that it is unclear how the market correctly uses all relevant information in determining security prices, if investors have heterogeneous information (Leroy 1989). In the spirit of an information economics approach, Grossman (1976) also notices a paradox in Fama's (1970) definition.

If prices fully reflect all available information, there is no reason for an investor to search for information in his decision-making of buying and selling different stocks. How could the prices fully reflect the information if no one searched for information? Grossman and Stiglitz (1980) analyzed this paradox and presented the model where the prices partially reflect the information that arbitrageurs possess. Their theory was based on two types of investors, informed and uninformed. If the market is efficient, where information is associated with a cost, the informed individuals would not able to get any compensation from the uninformed individuals, since the information will be fully reflected in the stock prices.

However, they also found certain noise in this model, which implied that stock prices could not reflect all information. If the market price were perfectly informative, there would be little incentives for investors to search and pay for additional information for their decision-making (Grossman and Stiglitz, 1980; Latham, 1986). This work has led to the development of a large body of literature that attempted to redefine the notion of the efficient markets (Findlay and Williams, 2000).

More recently, Malkiel (1992) extends Fama's definition by including two dimensions: in efficient markets, security prices would be unaffected by revealing the relevant information to all participants. Second, it is impossible to make a profit by trading on this set of information. Therefore, the market efficiency can be judged by measuring profits made by trading on the information. This view is closely related to the definition of market efficiency provided by Jensen (1978); Campbell et al. (1997: 22); Timmermann and Granger (2004). However, their definitions are concerned with information and transaction costs, but do not involve testing the joint hypothesis (Pesaran, 2005). 
Based on the above different discussion, we may conclude that even if there are various critics of Fama's (1970) definition and redefinitions of the concept, his definition of efficient markets is still the most commonly used standard and benchmark for determining market efficiency and relative market efficiency.

\section{Conceptual Issues}

Since the seminal work on the balance of payments crises and speculative attacks by Krugman (1979), the literature of financial crises has evolved over time. The first generation of models (see, for example, Krugman, 1979 and Flood and Garber, 1984) dealt with the un-sustainability of a fixed currency peg due to the inconsistency between money creation for the financing of budget deficit and the maintenance of the peg that required monetary policy to be amenable to the defense of the currency. Rational agents aware of this "vulnerability" would engage in a speculative attack on the exchange rate, which triggers exchange rate adjustments (Krugman, 1979 and Flood and Garber, 1984).

Later models (Flood, Garber and Kramer, 1996; Flood and Marion, 1996) extend the analyses to include scenarios where monetary authorities are non-passive as well as cases where uncertainties exist. However, these models were premised on the existence of weaknesses in macroeconomic fundamentals, and a key element missing in the first generation models is the existence of contagion and contagion effects.

The second-generation models of financial crises focused on the existence of multiple equilibria as an explanation for currency and banking crises, best captured in the papers by Obstfeld $(1986,1994)$. Obstfeld said that crises occur as a result of the movement from one equilibrium to another, which can be alluded to as a "bad" equilibrium, through nonlinearities in government behavior. These nonlinearities are often triggered by incompatibilities between the expectations of agents and government signals or incentives. Second generation models also spawned the possibility of herd behavior as a cause of currency and financial crises.

In the aftermath of the Asian financial crisis, a new theoretical strand emerged - one that emphasized moral hazard as well as contagion (Chang and Velasco, 1998; Corsetti, Pesenti and Roubini, 1999) as the missing links that could possibly reconcile the two disparate trends between the first generation fundamental-based and the second generation self-fulfilling, multiple equilibria-based models.

Agents in the market form expectations based on the current information set, and if markets are sufficiently competitive, then investors cannot expect to achieve superior profits from their investment strategies based on their information set. This is because "in competitive market, there is a buyer for every seller. If one could be sure that a price would rise, it would have already risen" (Samuelson, 1965).

By way of contrast, the inefficiency of the market has several implications. First, the share prices may not necessarily reflect the true value of stocks. So, companies with low true values may be able to mobilize a lot of capital, while companies with high true values may find it difficult to raise capital. This disrupts the investment scenario of the country as well as the total productivity. Second, market inefficiency may imply mean reversion of prices that may cause expected returns to vary. Third, market inefficiency may imply excess price volatility in the short run because prices change 
by more than the value of the new information. Last but not the least; weak form market inefficiency may have a positive impact on the process of financial innovation. In a state of market inefficiency, opportunities for supernormal profit exist because the future prices can be predicted following the information contained in past prices. So the expectation for excess profit will stimulate short run investment which may act as the best incentive for introducing sophisticated new financial products to exploit the environment (Chang and Velasco, 1998).

Certainly, the existence of excessive volatility, or "noise," in the stock market undermines the usefulness of stock prices as a "signal" about the true intrinsic value of a firm, a concept that is core to the paradigm of the informational efficiency of markets (Karolyi, 2001).

It is important to constantly document developments in the global stock markets, especially in the face of globalization. An accumulation of such information will also provide a platform for determining the integration of a global stock market or lack of it. Since the global markets encapsulate stock markets located in developed and emerging economies, it is of scholarly interest to find out if the pattern of returns and volatilities change over time or have a strong correlation to the development status of the countries where the stock market is located, and hence, the need for this kind of study from time to time.

In this vein, it is common to distinguish two types of channels for an international transmission of crisis, such as had occurred with the US subprime crisis: (1) "Common Shocks" whereby financial sectors in different countries are concurrently affected by the same development; and (2) Spill-over effects or "Contagion" whereby the impact of the shock on the US financial market and economy are subsequently transmitted elsewhere (Stevens, 2008).

The common shocks take two forms. One is the existence of exposure of both US and international investors and financial institutions to increased default risk of securities linked to the US sub-prime market. This has been of importance in the transmission effects to Europe with many notable instances of write-downs of the market value of asset portfolios. The second common shock, reflecting the integrated nature of international investments, is the marked increase in risk aversion and liquidity preference of investors worldwide. Again, this was noticeable in European markets, both in interbank markets and in wholesale debt markets (Bank of England, 2007; European Central Bank, 2007).

Didier et al. (2007) identify two types of spillover of contagion. One is via "real economy" effects such as the international transmission of aggregate demand and trade flow effects from the impact of the crisis of the US economy. While this might be expected to involve lagged effects spread over time, "rational" expectations and resulting actions particularly of financial market participants may speed up the effects. For example, the sensitivity of equity market prices, and thus the cost of capital, to changed economic growth projections may be relatively rapid.

A second type of spillover effect rises from the interrelationships of the global debt and the equity market. For example, changes in asset prices in one market will be transmitted to other markets internationally through portfolio adjustments by intermediaries and investors. Similarly, shocks to liquidity and asset quality in particular markets will lead to balance sheet adjustments by banks, fund managers, and others operating internationally. These effects may be transmitted by asset market adjustments or by financial institutions (Didier et al., 2008). 
In the former case, changes in market prices provide a rapid sign of effects whereas the opacity of the banking sector means that public information about effects may be more delayed and reflected in announcements about asset value write downs and provisioning. In general, interactions between adjustments in asset markets and actions of intermediaries play an important role in generating and transmitting financial fragility and creating systemic crises because of the important role of liquidity (Allen and Gale, 2007). This paper focuses on this second type of spillover and emphasizes equity volatility transmission.

\section{Review of Empirical Studies}

Since the recent global crisis in the US sub-prime came into the open, many studies have been carried out to report its impacts on the domestic and international economy. However, different results were presented perhaps due to differences in the methodological instruments and scope of the studies.

Soludo (2009) identified five ways in which the global economic and financial crisis impacted the global economy: declining real output growth leading to slowed economic growth; weakened financial systems leading to takeovers and bankruptcy; loss of jobs; loss of confidence in financial markets leading to inability to carry out their intermediation role in the economy; and stock market crashes. The evidence provided in the paper showing how the global economic and financial crisis has affected economies did not adopt any econometric technique to measure the impact. However, a major strength of the study was that it identified the stock market as a transmission channel through which the global economic and financial crisis impact on economies across the globe.

An earlier paper that also identified the stock market as a transmission channel of the global economic and financial crisis into the economies of less developed countries was the study by Te Velde (2008). The study noted that the global economic and financial crisis has dragged stock markets down by more than $40 \%$. The paper provided trend analysis to justify the size of the impact. Coleman (2008) examined the impact of the global economic and financial crisis on African economies. The study provided trend evidence as well arguing that the crisis has affected selected African stock markets. The study examined the indicators of two developed stock markets, the Dow Jones Industrial Average (DJIA) and FTSE, and three African stock markets, the Johannesburg Stock Exchange (JSE), Nigerian Stock Exchange (NSE) and Cairo Stock Exchange (CASE) over a period of 12 months (November 2007 to November 2008). The central conclusion drawn from the study relating to the selected African stock market was that African capital markets have fallen by $30-40 \%$ over the study period but private equity investors remained committed to Africa.

The African Development Bank (2009) in studying the impact of the global economic and financial crisis on Africa drew certain conclusions that are of importance for this present study. Among other arguments, they noted that Africa was not severely affected by the global economic and financial crisis because of its low level of financial integration with the developed economies. The study identified two transmission channels of the crisis into Africa: trade flows and capital flows (such as foreign direct investment-FDI, private capital flows and remittances).

Similar study by the International Monetary Fund (2009) however noted that Low Income Countries (LICs) are exposed to the current global downturn now more than in previous episodes because they are more integrated than before with the world economy through trade, FDI, and remittances. Though 
the study by the IMF and the ADB identified the same channels of transmission, they differ in their argument concerning the level of integration of the African economy with the rest of the world. These channels of transmission were also acknowledged in Fundanga's (2009) speech.

The study by the Economic Commission for Africa (ECA) and the African Union Commission (AUC) in 2009 pointed out that the global economic and financial crisis was not expected to impact African economies because of the low integration of Africa into the global economy. The study further noted that recent developments have, however, shown that the negative contagion effects of the crisis are already evident in the Africa region. On the impact of the crisis on African stock markets, the study noted that the global economic and financial crisis has had a direct impact on Africa. The study argued that stock market volatility in Africa has increased, leading to losses of wealth in major stock exchanges such as Egypt, Nigeria and Kenya.

Te Velde et al. (2009), in their synthesis of the ten draft country report, documented that the main transition belts of the global economic and financial crisis are trade, private capital flows, remittances and aid. The study also noted that portfolio investment flows experienced a dramatic drop in 2008 in most countries, shifting sometimes to large net outflows and a significant drop in equity markets in 2008 and into 2009. Clearly, the study showed that stock markets (equity markets) are a veritable channel of transmission of the global economic and financial crisis into the economies of less developed countries.

Abraham (2010) employed econometric methods concentrating on a during-crisis empirical study. From his findings, he submitted that both on a general and on specific notes, the stock market is a viable transmission mechanism of the global economic and financial crisis to Africa due to evidence of stock market integration found between selected African stock markets and those of the US and the UK. In terms of the extent to which the crisis impacted African stock markets, the study found a positive/significant relationship between the selected African stock markets and those of the US/UK. Beyond this, he concluded that about $30 \%$ of the variation in the selected African stock markets (over the period 10 December 2007 to 3 July 2009) was attributed to the variations from developed stock markets in the US and the UK. However, it can be argued that his study could be fraught with 'data doubling' as the crisis does not concurrently run in the US and UK but rather it spills from the former to the latter (Abraham, 2010).

From the foregoing, it becomes highly imperative to embark on a study using econometric background with a dichotomy of prior and concurrent analyses of the global contagion on stock markets in African countries as well as the volatility or otherwise, with the main aim of determining the efficiency status of the stock markets, of these countries during the said periods. This will not only clear the air around the unsettled issues about the impact of the former on the latter but show whether the crises and attendant volatility in the market make market stakeholders wiser in information dissemination and usage.

Within the context of methodological issues, generalized autoregressive conditional heteroscedasticity $(\mathrm{GARCH})$ and its variants have been used largely to determine the volatility of stock market returns. Therefore, the introduction of ARCH and GARCH models by Engle (1982) and Bollerslev (1986), respectively, has introduced an explosive research into the dynamics of conditional stock market volatility. 
Precisely, Bollerslev (1986) generalized the ARCH model by modeling the conditional variance to depend on its lagged values as well as squared lagged values of disturbance, called generalized autoregressive conditional heteroskedasticity $(\mathrm{GARCH})$. Some of the models include IGARCH originally proposed by Engle and Bollerslev (1986), GARCH-in-Mean (GARCH-M) model introduced by Engle, Lilien and Robins (1987), the standard deviation GARCH model introduced by Taylor (1986) and Schwert (1989), the EGARCH or Exponential GARCH model proposed by Nelson (1991), TARCH or Threshold ARCH and Threshold GARCH were introduced independently by Zakoïan (1994) and Glosten, Jaganathan, and Runkle (1993), and the Power ARCH model generalized by Ding, Granger, and Engle (1993) among others.

If investors are risk averse, theory predicts a positive relationship should exist between stock return and volatility (Leon, 2007). If there is a high volatility in a stock market, the investors should be compensated in the form of higher risk premium. The GARCH-in-Mean (GARCH-M) model introduced by Engle, Lilien and Robins (1987) has been used by various researchers to examine the relationship between stock return and volatility (see French, Schwert and Stambaugh, 1987; Chou, 1988; Baillie and DeGennaro, 1990; Nelson, 1991; Glosten et al., 1993, and Léon, 2007 among others).

Mixed results were found by various authors. Some found the relation between the risk and return to be positive (French, Schwert and Stambaugh, 1987; and Chou, 1988; among others) while others found it negative (Nelson, 1991; Glosten et al., 1993 among others). Little or no work has been done on modeling stock returns volatility in Africa, particularly using EGARCH models. This paper attempts to fill this gap.

\section{TREND OF STOCK MARKET DEVELOPMENT IN AFRICA: PRIOR AND DURING-CRISIS REVIEW}

Stock markets in Africa expanded considerably after 1989 (Sebnet and Ochere, 2008). Until then, there were only ten stock markets: the Alexandria Stock Exchange (1881), Johannesburg Security Exchange (1887), Cairo Stock Exchange (1903), Casablanca Stock Exchange (1929), Nairobi Stock Exchange (1954), Nigerian Stock Exchange (1960), Bourse de Tunis (1969), The Stock Exchange of Mauritius (1988), Bond Exchange of South Africa (1989), and Botswana Stock Exchange (1989). The Cairo and Alexandria Stock Exchange merged in 1997. Since 1989, the stock markets have increased to over twenty in Africa (Ngo-Mambongo and Lawal, 2008).

Indicators of stock market development as presented in Table 2 show that African markets are small with few listed companies and low market capitalization. Egypt, Nigeria, South Africa and Zimbabwe are the exceptions with 792, 207, 403 and 79 companies listed respectively.

Specifically, the average number of listed companies in sub-Saharan African markets excluding South Africa, is 39 compared with 113 with the inclusion of Egypt and South Africa. Market capitalization as a percentage of GDP is as low as 1.4 in Uganda. The Johannesburg Securities Exchange in South Africa has about $90 \%$ of the combined market capitalization of the entire continent. Excluding South Africa and Zimbabwe, the average market capitalization is about $27 \%$ of GDP. This is in contrast to other emerging markets like Malaysia with a capitalization ratio of about $161 \%$. 
Table 2

Indicators of Stock Market Development in Africa, 2004

\begin{tabular}{lcccc}
\hline Africa Countries & $\begin{array}{c}\text { No. of Listed } \\
\text { Companies }\end{array}$ & $\begin{array}{c}\text { Market } \\
\text { Capitalization } \\
\text { of GDP) }\end{array}$ & $\begin{array}{c}\text { Volume of Trade } \\
(\% \text { of GDP) }\end{array}$ & Turnover (\%) \\
\hline Botswana & 18 & 29.4 & 0.6 & 2.1 \\
Egypt & 792 & 51.3 & 7.5 & 17.1 \\
Ghana & 29 & 30.7 & 0.8 & 3.2 \\
Kenya & 47 & 24.9 & 2.1 & 8.0 \\
Malawi & 8 & 9 & 1.0 & 11.1 \\
Mauritius & 41 & 39.3 & 1.6 & 4.4 \\
Namibia & 13 & 8.1 & 0.3 & 4.7 \\
Nigeria & 207 & 20.1 & 2.3 & 13.9 \\
South Africa & 403 & 214.1 & 76.5 & 45.0 \\
Swaziland & 6 & 9.3 & 0.0 & 0.0 \\
Tanzania & 6 & 6.2 & 0.2 & 2.5 \\
Uganda & 5 & 1.4 & 0.0 & 0.2 \\
Zambia & 11 & 8.0 & 0.1 & 1.1 \\
Zimbabwe & 79 & 87.9 & 14.0 & 3.9 \\
Average Africa & 113.6 & 36.9 & 7.2 & 8.0 \\
Average SSA & 39.2 & 22.1 & 1.8 & 4.4 \\
Malaysia & 965 & 161.3 & 50.8 & 34.4 \\
Mexico & 152 & 25.4 & 6.3 & 93.8 \\
Thailand & 465 & 70.6 & 66.7 & \\
\hline
\end{tabular}

Source: World Bank, World Bank Development Indicator (2004). *Excluding South Africa.

Also, African stock markets suffer from the problem of low liquidity. Liquidity as measured by the turnover ratio is as low as $0.02 \%$ in Swaziland compared with about $29 \%$ in Mexico. Low liquidity means that it will be harder to support a local market with its own trading system, market analysis, brokers, and the like because the business volume would simply be too low: however, despite the problems of small size and low liquidity, African stock markets continue to perform remarkably well in terms of return on investment.

In 2004, six African countries (Ghana, Uganda, Kenya, Egypt, Mauritius and Nigeria) were among the world's ten (10) best-performing markets with the Ghana Stock Exchange adjudged the world's bestperforming market at end of the year 2004. It had a year's return of 144\% in US dollar terms compared with 30\% return by Morgan Stanley Capital International Global Index (Databank Group, 2004). Moreover, in 2005, Egypt, Uganda and Zambia were in the top five (5). In 2006, Malawi outperformed every other market in the world. Within the continent itself, five other bourses-Uganda, Kenya, 
Egypt, Mauritius and Nigeria apart from Ghana-were amongst the best performers in the year, prior to the global crisis.

More emphatically, before the global financial meltdown, Africa had developed and expanded the equity market sector in a very short time. The number of operating stock exchanges rose from just ten (10) in 1989 to twenty three (23) in 2007, reaching a total market capitalization of over \$2.1 trillion. Despite their small size and low liquidity, many African markets offered dramatic return to investors over time. There has been at least one African stock market in the top ten (10) best-performing markets in the World every year since 1995 (Massa, 2009).

The shock waves of the global financial crisis have reached Africa, hitting some of the key drivers of stock market development. First, tighter credit conditions and gloomy growth prospects worldwide, plus increased risk aversion have reduced foreign investors' appetite for investment in African markets. FDI slowed in 2008, and portfolio equity flows have slowed down or even reversed alongside the sharp fall in equity prices (Brambila and Massa, 2009).

The Nigerian Stock Exchange (NSE), for example, fell 46\% in 2008, becoming the world's worst performing market. In addition to the drying up of external resources, anecdotal evidence shows that private sector credit growth has decreased in some African countries like Nigeria, while domestic bank lending conditions have become stringent in other countries like Zambia. This had a negative impact on banking sector development, which plays a complementary rather than a substitute role for stock market development in Africa.

Remittances, which are positively related to stock market development (Billmeier and Massa, 2009), grew at a lower rate in 2008 and are forecast to decline by more than 8\% in sub-Saharan Africa in 2009 alone (Massa, 2009).

Findings from Chart 1 show that the size of stock markets in Africa maintained a steady rise between the prior-crisis years of 2005-2007. Though with a constant debt securities between these years, the bank assets which were constant between 2005 and 2006, increased by $29.2 \%$ in 2007 while the market capitalization has constantly been on the increase.

\section{Chart 1}

Size of Capital Markets in Africa: Prior to Global Economic Crisis

Size of Capital Markets in Africa

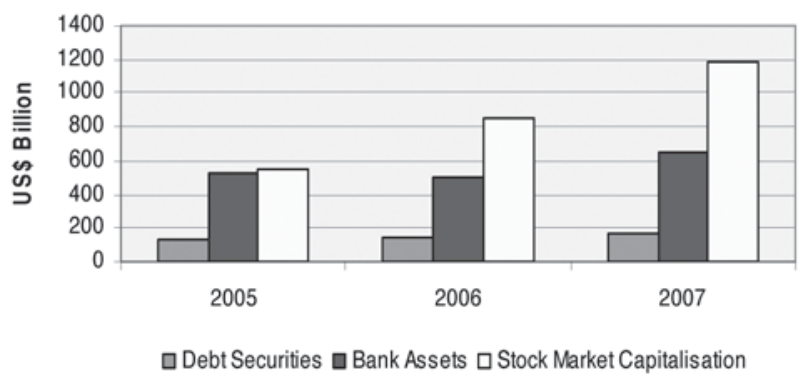

Source: Kesekende, 2008 
The stock market capitalization increased by $75.0 \%$ from US $\$ 480$ billion in 2005 to US $\$ 840$ billion in the year 2006 and further by $41.7 \%$ in 2007 from US\$840 billion in 2006 to US $\$ 1,190$ billion.

Table 3 and Charts 2-5 indicate to what proportion and to what extent the global economic crisis has affected the development in the African stock markets. From the relatively highly capitalized Kenyan stock market to the lowly capitalized Nigerian stock market, the effect of the global economic crisis is felt across the board, though in varying proportions.

Table 3

Indicators of Stock Market Development in Africa: 2006-2008.

\begin{tabular}{|c|c|c|c|c|c|c|}
\hline \multirow[b]{2}{*}{ Africa Countries } & \multicolumn{2}{|c|}{$\underline{\text { Year } 2006}$} & \multicolumn{2}{|c|}{$\underline{\text { Year } 2007}$} & \multicolumn{2}{|c|}{$\underline{\text { Year } 2008}$} \\
\hline & NLC & $\begin{array}{c}\mathrm{MC}(\% \text { of } \\
\text { GDP) }\end{array}$ & NLC & $\begin{array}{c}\mathrm{MC}(\% \text { of } \\
\text { GDP) }\end{array}$ & NLC & $\begin{array}{c}\mathrm{MC}(\% \text { of } \\
\text { GDP) }\end{array}$ \\
\hline Botswana & 18 & 36 & 18 & 48 & 19 & 27 \\
\hline Egypt & 603 & 87 & 435 & 107 & 373 & 53 \\
\hline Ghana & 32 & 25 & 32 & 16 & 35 & 20 \\
\hline Kenya & 51 & 51 & 51 & 49 & 53 & 36 \\
\hline Malawi & 10 & 19 & 9 & ' & 14 & 41 \\
\hline Mauritius & 41 & 55 & 90 & 75 & 41 & 37 \\
\hline Namibia & 9 & 7 & 9 & 8 & 7 & 7 \\
\hline Nigeria & 202 & 22 & 212 & 52 & 213 & 24 \\
\hline South Africa & 401 & 277 & 422 & 294 & 425 & 178 \\
\hline Swaziland & 6 & 7 & 6 & 7 & 7 & ", \\
\hline
\end{tabular}

Source: World Bank, World Bank Development Indicator (2009)

NLC - No of Listed Companies; MC - Market Capitalization.

\section{Chart 2}

Trend in No. of Listed Companies (NLC) to Market Capitalization in Nigeria before and during the Global Economic Crisis of 2006 - 2008.

Size of Capital Markets in Africa

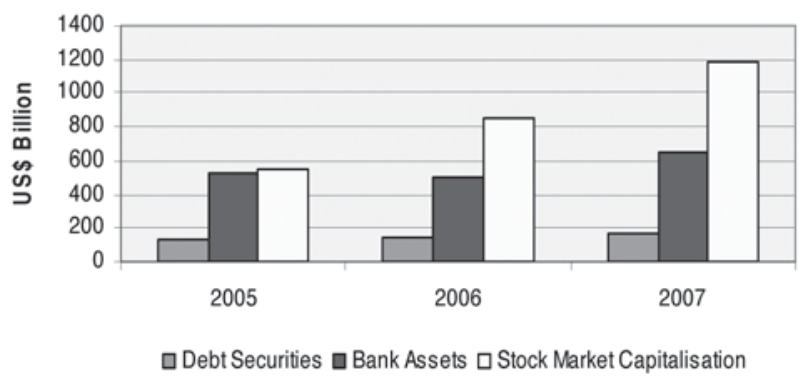




\section{Chart 3}

Trend in No. of Listed Companies (NLC) to Market Capitalization in South Africa before and during the Global Economic Crisis of 2006 - 2008

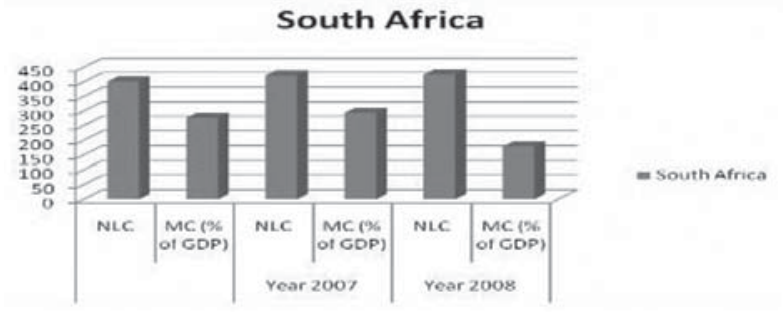

\section{Chart 4}

Trend in No. of Listed Companies (NLC) to Market Capitalization in Kenya before and during the Global Economic Crisis of 2006 - 2008

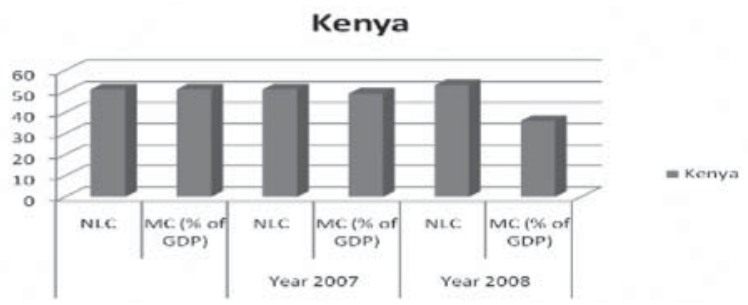

\section{Chart 5}

Trend in No. of Listed Companies (NLC) to Market Capitalization in Egypt before and during the Global Economic Crisis of 2006 - 2008

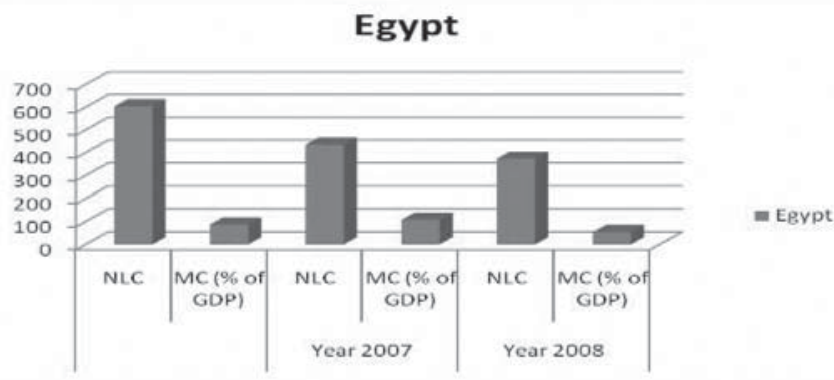

The effect is that the development in the Nigerian stock market declined to the two years\&\#8217; previous level; that is, the global crisis in 2008 actually returned the Market Capitalisation of the Nigerian stock market to its earlier in 2006 while those of Johannesburg, Kenyan and Cairo stock markets in 2008 were lower than their 2006 value.

Thus, there was a $39.08 \%$ in the drop of market capitalization for the Cairo stock market, $29.41 \%$ for the Kenyan stock market and $35.74 \%$ for the Johannesburg stock market between the years 2006 (prior-crisis period) and 2008 (crisis period). 


\section{Graphical Trends of All Share Index of Selected African Countries (African Stock Market Surrogates): Pre, During- and Post-Crisis Trends}

The graphical illustrations (Charts 6-9) suggest that relative differences exist in timing for the impacts of the global contagion felt by these African surrogate countries. The intensity of the contagion was greater in the Nigerian case than the Cairo stock market. In Nigeria, the stock market experienced a free fall immediately after the effect of the global crisis became manifest. This might be linked to the sudden and persistent capital outflow from the market within the period.

However, the Johannesburg case was cyclical in nature at the start, suggesting that the stock market earlier weathered the storm of global economic crisis earlier but then lost the 'fight,' perhaps when the effect became more intense.

The decline in the United States stock market was not as evident as in the African countries. This could imply that capital movement in the US stock market was not as severe as in those African countries in which foreign participation was quite significant.

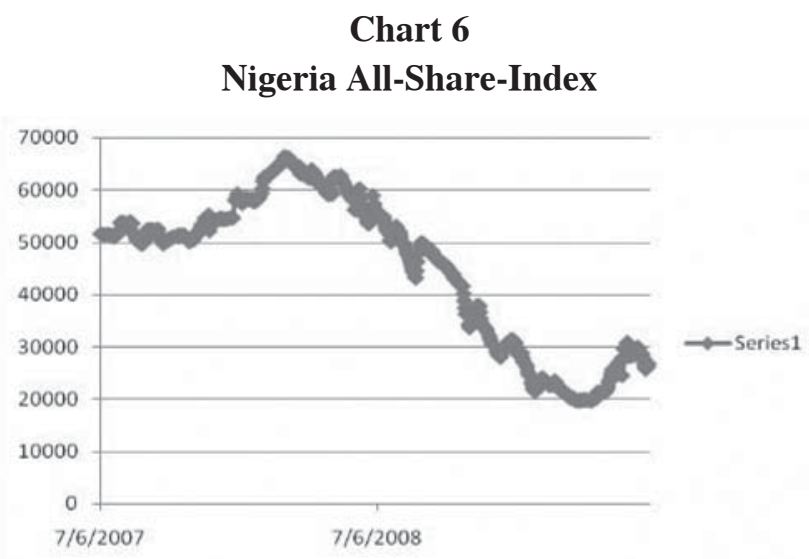

\section{Chart 7}

South Africa All-Share-Index

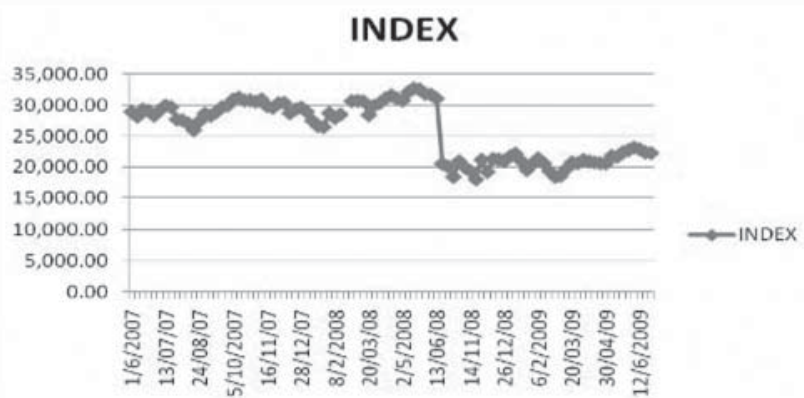


Chart 8

Egypt All-Share-Index

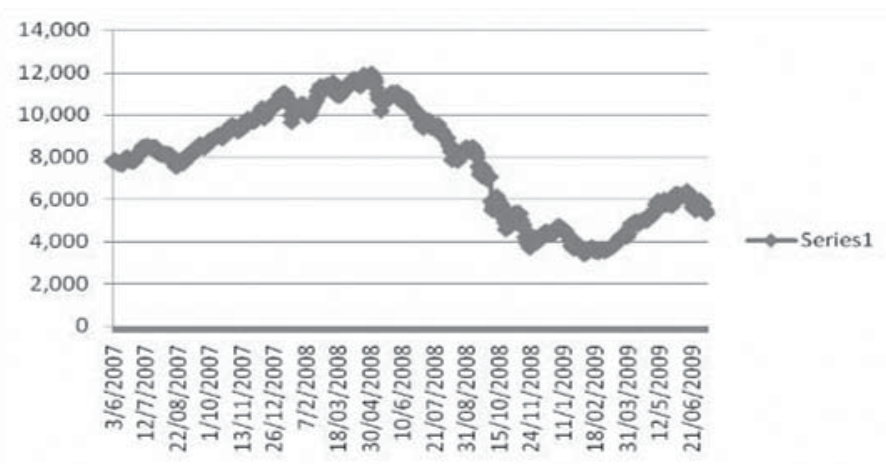

Chart 9

United States of America All-Share-Index

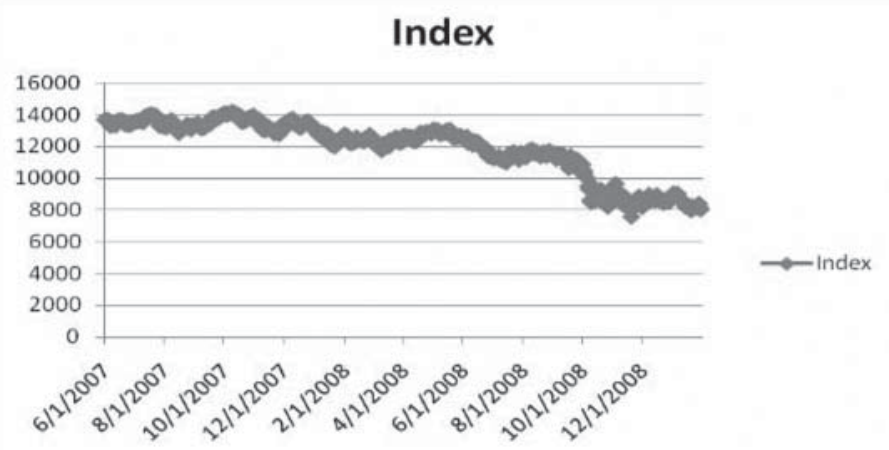

\section{METHODOLOGY AND ANALYTICAL FRAMEWORK}

Prior to the specification of the methodological framework for this study, it should be noted that we are betting on the null hypothesis that the global economic and financial crisis does not significantly improve the efficiency of stock markets in emerging markets, with particular reference to African countries. In order to avoid 'lopsidedness' in estimation, this study intends to carry out both a holistic and country-specific investigation within the context of pre- during- and post-crisis estimations. These will afford us the opportunity to establish whether consistency prevails within these three periods.

Our choice of taking the Nigerian Stock Exchange, Johannesburg Stock Exchange and the Cairo Stock Exchange as the surrogates for the continent of Africa is informed by the fact that these are the highly performing stock markets in Africa (see Tables 2 and 3) prior to the occurrence of the global crisis and 
its consequential contagion on stock markets the world over. Therefore, the impacts of contagion on these markets could be valid for continental generalization. Also, the use of the Dow Jones Industrial Average (DJIA) as the anchor exchange is based on some recent empirical studies (see Tella, 2009).

\section{Data Sources}

The data employed for this research work are primarily the daily total stock market index of the selected African countries, viz the Nigeria Stock Index (NSI), the Johannesburg Stock Index (JSI) and the Cairo Stock Index (CSI). It is coupled with the Dow Jones Index (DJI) for the United States of America while following the work of Abraham (2010); the data for the African Stock Index is an average value for the three surrogate countries of Cairo, Johannesburg and Nigeria Stock Indices. These data are extracted from the respective countries' official websites such as www.nigerianstockexchange.com, www.jse.co.za, www.case.com, and www.nyse.com. Also, to facilitate the trends analysis of this work, data are sourced from the World Development Indicator (WDI, 2009).

\section{Tests of Analysis}

In order to lend credence to this study, we obtain some summary statistics such as the mean, median, standard deviation, maximum and minimum values, skewness and kurtosis which assist us in confirming the average and dispersion properties of our stock data.

Concomitantly, a series of diagnostic tests such as the Ljung-Box Q-test and Ljung-Box $\mathrm{Q}^{2}$-test statistics were later used to diagnose the models for the absence of specification bias. While the former will check for the mean equations, the latter will be more appropriate for the variance equations. The ARCH-ML test was also used to assist in ascertaining if the standard residuals exhibit additional ARCH Effects (Olowe, 2009).

Additionally, since most economic data are said to be fraught with a unit-root problem i.e. the means and variances are time dependent and such variables are said to be I(1) (Holden and Perman; 1974), the validity or otherwise of this assertion was established through the use of Augmented Dickney Fuller (ADF) and the Phillip-Perron tests of stationarity. The ADF test shows that any dynamic specification of the model in the levels of their series is likely to be inappropriate and may be plagued with problems of spurious regression (Green, 2003).

\section{Summary Statistics and Autocorrelation of Raw Stock Return: Pre-, During- and Post-Crisis Periods}

The summary statistics displayed in Tables 4-6 suggest that the mean returns for African stock markets of the prior-, during- and post-crisis period are $0.00134,0.00037$ and -0.00066 while its standard deviations are $0.104687,0.127092$, and 0.01878 respectively. This signifies that the mean return appears to be positive prior to and during the global crisis but both turned negative afterwards showing that on the average, investors did not really sustain losses during these periods, except in the post-crisis period. The behavior of the standard deviation shows a positive relationship between risk and return (as depicted by standard deviation and mean respectively) since it appears lowest in the post-crisis period. 
Similarly, the respective stock markets of Nigeria and Johannesburg share the same attributes with the African stock markets as the behavioral patterns of mean returns and risk levels of stock (denoted by standard deviation) in all respects. For the Nigerian case, the mean returns during the prior-, during- and post-crisis periods are $0.001319,0.000115$, and -0.00115 while its risk levels are $0.209008,0.206046$ and 0.02433 respectively. Also, the Johannesburg stock markets has a mean return of 0.001244 , 0.000402 , and -0.00000497 with the risk levels of $0.011904,0.200260$, and 0.01632 respectively for the periods under review.

Table 4

Summary Statistics and Autocorrelation of Raw Stock Return Prior to the Crisis Period 01/02/2006-29/12/2006

\begin{tabular}{lcccc}
\hline STATISTICS & AFRICA & CASE & NSE & JSE \\
SUMMARY STATISTICS & & & & \\
\hline Mean & 0.00113 & 0.00029 & 0.00132 & 0.00124 \\
Medium & 0.00064 & 0.00190 & 0.00000 & 0.00000 \\
Maximum & 1.15204 & 0.06837 & 2.29886 & 0.05537 \\
Minimum & -1.14302 & -0.07931 & -2.29366 & -0.07716 \\
Standard Deviation & 0.10469 & 0.02095 & 0.20901 & 0.01190 \\
Skewness & 0.09573 & -0.53965 & 0.01822 & -1.27485 \\
Kurtosis & 119.816 & 4.80746 & 120.904 & 19.9935 \\
Jarque-Bera & 138168 & 44.8719 & 140751 & 2989.71 \\
Probability & 0.00000 & 0.00000 & 0.00000 & 0.00000 \\
Observation & 243 & 243 & 243 & 243 \\
\hline
\end{tabular}

Table 5

Summary Statistics and Autocorrelation of Raw Stock Return During the Crisis Period 30/06/2007-31/12/2008

\begin{tabular}{lcccc}
\hline STATISTICS & AFRICA & CASE & NSE & JSE \\
SUMMARY STATISTICS & & & & \\
\hline Mean & 0.00037 & 0.001452 & 0.000115 & 0.000402 \\
Medium & 0.000173 & 0.002585 & 0.0000 & 0.0000 \\
Maximum & 1.333553 & 0.041954 & 2.340831 & 2.293663 \\
Minimum & -1.34608 & -0.04772 & -2.27905 & -2.35631 \\
Standard Deviation & 0.127092 & 0.012781 & 0.206046 & 0.200260 \\
Skewness & -0.11058 & -0.58777 & -0.10903 & 0.103120 \\
Kurtosis & 97.17769 & 4.297313 & 129.3575 & 130.1997 \\
Jarque-Bera & 97194.78 & 33.58631 & 174963.5 & 177303.7 \\
Probability & 0.0000 & 0.0000 & 0.0000 & 0.0000 \\
Observation & 263 & 263 & 263 & 263 \\
\hline
\end{tabular}


Table 6

Summary Statistics and Autocorrelation of Raw Stock Return Post- Crisis Period 01/01/2009-30/06/2009

\begin{tabular}{lcccc}
\hline STATISTICS & AFRICA & CASE & NSE & JSE \\
SUMMARY STATISTICS & & & & \\
\hline Mean & -0.00066 & 0.00156 & -0.00115 & $4.97 \mathrm{E}-06$ \\
Medium & -0.00131 & 0.00195 & -0.00189 & 0.00000 \\
Maximum & 0.09320 & 0.05830 & 0.12703 & 0.05841 \\
Minimum & -0.07585 & -0.06181 & -0.10689 & -0.07134 \\
Standard Deviation & 0.01878 & 0.02314 & 0.02433 & 0.01632 \\
Skewness & 0.55495 & -0.19354 & 0.66202 & -0.37898 \\
Kurtosis & 8.70625 & 2.82819 & 10.7996 & 11.3575 \\
Jarque-Bera & 173.190 & 0.91916 & 320.757 & 360.917 \\
Probability & 0.00000 & 0.63155 & 0.00000 & 0.00000 \\
Observation & 123 & 123 & 123 & 123 \\
\hline
\end{tabular}

However, the Cairo stock market has mean returns and standard deviation during the periods under review that indicate that the Cairo stock market did not suffer the effect of contagion during or even after the global economic crisis. The mean returns prior-, during- and post-crisis periods for the Cairo stock market are $0.000287,0.001452$, and 0.00156 with standard deviations of $0.020948,0.012781$, and 0.02314 respectively. This indicates that the average market return is even better during the crisis than prior to but performs best in the post-crisis period. The risk is also positively related to the returns too as an increasing return is accorded with an increasing risk.

Additionally, the skewness of the data series indicates an asymmetric or non-normal data distribution as the series deviates widely from normality maintaining both positive and negative skewnesses. The African stock returns are positively skewed in the prior- and post-crisis periods with 0.09573 and 0.55495 coefficients, but -0.11058 during the crisis period. The Nigerian stock market returns also share a similar distribution with $0.01822,-0.10903$, and 0.66202 in the prior-, during- and post-crisis periods respectively. The Cairo stock returns maintain negative skewness for all periods under study with $-0.53965,-0.58777$, and -0.19354 coefficients respectively while the Johannesburg stock market returns were skewed negatively pre- and post crisis periods with -1.274585 , and -0.37898 coefficients, but positively during the global crisis with 0.10312 coefficient.

With a 3.0 benchmark for the Kurtosis of a normally distributed series, it is only the Cairo stock market that could be said to be normally distributed, especially during the post-crisis period as it has $4.80746,4.2973$, and 2.82819 for the pre-, during- and post-crisis periods respectively. For the cases of Africa, Nigeria and Johannesburg, the kurtoses obtained are very high suggesting highly peaked distributions, that is, they are leptokurtic in nature for the periods under review. 
In summary, the analysis of the stock returns confirmed that the empirical distribution of returns in the African stock returns market, except that of the Cairo market, was of asymmetric distribution, and with very thick tails. The leptokurtosis reflected the fact that the market was characterized by very frequent medium or large changes. These changes occurred with greater frequency than what was predicted by the normal distribution. The empirical distribution confirmed the presence of a nonconstant variance or volatility clustering.

\section{Augmented Dickney Fuller and Phillip-Peron Tests}

The results of the Augmented Dickney Fuller (ADF) and Phillip-Peron tests are presented in Table 7. Aimed at strengthening the estimates obtained in our specified models, it showed that, during the global economic crisis period of 30/06/2007 - 31/12/2008, stationarity was obtained at levels $\mathrm{I}(0)$ for the holistic variable of Africa as well as the individual variable for the surrogates African countries. The exception was Egypt (herein proxied as CASE) which only maintained stationarity at an order of integration 1 , that is $\mathrm{I}(1)$.

Table 7

Augmented Dickney Fuller (ADF) and Phillip-Peron Tests of Unit Root Prior to Global Economic Crisis: 30/06/2006-31/12/2006

\begin{tabular}{|c|c|c|c|c|c|}
\hline \multirow[b]{2}{*}{ Variables } & \multicolumn{2}{|c|}{$\underline{\text { ADF test statistic }}$} & \multicolumn{2}{|c|}{ Phillip-Perron test } & \multirow{2}{*}{$\frac{\text { PP Test }}{\begin{array}{c}\text { Order of } \\
\text { integration }\end{array}}$} \\
\hline & Levels & $1^{\text {st }}$ Difference & Levels & $1^{\text {st }}$ Difference & \\
\hline AFRICA & -4.589251 & - & -4.589251 & - & $\mathrm{I}(0)$ \\
\hline CASE & -1.208195 & -13.52498 & -1.208195 & -13.52498 & $\mathrm{I}(1)$ \\
\hline JSE & -0.781766 & -15.85878 & -0.781766 & -15.85878 & $\mathrm{I}(1)$ \\
\hline NSE & -4.942851 & - & -4.942851 & - & $\mathrm{I}(0)$ \\
\hline
\end{tabular}

However, in the after-crisis period of 01/01/2009-30/06/2009, all of the individual African surrogate countries and, indeed, the whole of African countries' stock markets were non-stationary at levels rather at an order of integration one, I(1). Additionally, in the prior-crisis period of 30/06/2006 31/12/2006, the South Africa stock market (JSE) and that of Egypt (CASE) were non-stationary at levels except at an order of integration 1, I(1), while the Nigerian stock market (NSE) and that of the whole African stock markets (AFRICA) were stationary.

The implications of the above findings is that except for the Egyptian stock market (which is found to be affected by the shock of the global contagion), African stock markets were individually and collectively efficient (since stationary at levels) in the face of the global economic crisis. Hence, the markets could be said to be volatile during the crisis period. However, after the crisis period, all of the African stock markets were, individually and collectively inefficient (since they were non-stationary at levels) and non-volatile. The prior-crisis period indicated that only the Nigerian stock market and the collective African stock markets were efficient (since they were stationary at levels) and volatile but a different finding ensued in looking at the South Africa and Cairo stock markets during this period, which were inefficient (they were non-stationary at levels) and non-volatile. 
Table 8

Augmented Dickney Fuller (ADF) and Phillip-Peron Tests of Unit Root during Global Economic Crisis: 30/06/2007-31/12/2008

\begin{tabular}{lccccc}
\hline Variables & \multicolumn{2}{c}{ ADF test statistic } & \multicolumn{2}{c}{ Phillip-Perron test } & 1st Difference \\
& Levels & 1st Difference & Levels & $\begin{array}{c}\text { Order of } \\
\text { integration }\end{array}$ \\
\hline AFRICA & -4.031954 & - & -4.031954 & - & $\mathrm{I}(0)$ \\
CASE & 0.727093 & -16.95271 & 0.727093 & -16.95271 & $\mathrm{I}(1)$ \\
JSE & -5.802551 & - & -5.802551 & - & $\mathrm{I}(0)$ \\
NSE & -4.319501 & - & -4.319501 & - & $\mathrm{I}(0)$ \\
\hline
\end{tabular}

Source: E-Views Output.

In the light of this, one might be tempted (as did Collins and Bekpe, 2004) to conclude that African stock markets were not affected by the spread of contagion from the global economic and financial crisis. This did not hold up in the evidence from the findings from the post-crisis period.

Table 9

Augmented Dickney Fuller (ADF) and Phillip-Peron Tests of Unit Root after Global Economic Crisis: 01/01/2009-31/06/2009

\begin{tabular}{lccccc}
\hline Variables & \multicolumn{2}{c}{ ADF test statistic } & \multicolumn{2}{c}{ Phillip-Perron test } & 1st Difference \\
& Levels & 1st Difference & Levels & $\begin{array}{c}\text { Order of } \\
\text { integration }\end{array}$ \\
\hline AFRICA & -1.602300 & -9.710851 & -1.602300 & -9.710851 & $\mathrm{I}(1)$ \\
CASE & -0.362487 & -8.834169 & -0.362487 & -8.834169 & $\mathrm{I}(1)$ \\
JSE & -1.478692 & -11.18034 & -1.478692 & -11.18034 & $\mathrm{I}(1)$ \\
NSE & -1.927619 & -10.25730 & -1.927691 & -10.25730 & $\mathrm{I}(1)$ \\
\hline
\end{tabular}

However, indications from the above findings suggest that the contagion effect of the global economic crisis took its time in spreading to the African region and its surrogate countries. The exception was Egypt which was considered to be inefficient in the weak form prior to the global crisis (see Table 7). But none of the other countries as well as the continent as a whole was spared after this period of global crisis, implying that there was some short lag as part of the effect of the global economic crisis.

But we may not base our conclusions solely on the unit root tests of the weak-form efficiency or otherwise of the stock markets since the ADF and the Phillip-Perron unit root tests only examined the existence of stochastic trend components. They did not detect the predictability in returns (Chung, 2006). The possible violation of the random walk hypothesis of the African, Cairo, Nigeria and Johannesburg stock returns needs to be examined further using the EGARCH - Exponential Generalized Autoregressive Heteroscedasticity. Therefore, this is considered next. 


\section{Model Specification and Analysis}

Since the introduction of ARCH and GARCH models by Engle (1982) and Bollerslev (1986), respectively, there has been an explosion of research looking for the dynamics of conditional stock market volatility.

The specification procedure for GARCH models includes determining time-varying volatility behavior as well as searching for the asymmetric effects of shocks on volatility. Also, the traditional measure of volatility as represented by variance or standard deviation is unconditional and does not recognize that there are interesting patterns in asset volatility; e.g., time-varying and clustering properties.

This study attempts to model the volatility as well as the efficiency or otherwise of African stock markets in the light of the global economic crisis through the use of EGARCH or Exponential GARCH model proposed by Nelson (2001). Hence, the models are as specified below:

$$
\begin{aligned}
& R_{\text {tafrica }}=\log \frac{\left(\text { ASI }_{t}\right)}{\left(\text { ASI }_{t-1}\right)} \\
& R_{\text {tus }}=\log \frac{\left(\text { DJIA }_{t}\right)}{\left(\text { DJIA }_{t-1}\right)}
\end{aligned}
$$

Where;

ASI $_{t}$ is the Stock Exchange Index for the African stock markets at time t; ASI $_{t-1}$ is the Stock Exchange Index for the Africa stock markets at the preceding period; DJIA is the Stock Exchange Index for the United States of America stock market at time $t$ and DJIA ${ }_{t-1}$ is the Stock Exchange Index for the United States of America stock market at the preceding period.

The models for this study are as thus specified in linear form:

Mean Equations:-

$$
\begin{aligned}
& \mathrm{R}_{\text {AFRICAt }}=\mathrm{b}_{0}+\mathrm{b}_{1} \mathrm{R}_{\text {AFRICAt-1 }}+\mathrm{b}_{2} \sigma_{\mathrm{t}}+\mathrm{b}_{3} \mathrm{USR}_{\mathrm{t}-1}+\varepsilon_{\mathrm{t}} \\
& \mathrm{R}_{\text {CASEt }}=\mathrm{b}_{0}+\mathrm{b}_{1} \mathrm{R}_{\text {CASEt- } 1}+\mathrm{b}_{2} \sigma_{\mathrm{t}}+\mathrm{b}_{3} \mathrm{USR}_{\mathrm{t}-1}+\varepsilon_{\mathrm{t}} \\
& \mathrm{R}_{\text {NSEt }}=\mathrm{b}_{0}+\mathrm{b}_{1} \mathrm{R}_{\text {NSEt }-1}+\mathrm{b}_{2} \sigma_{\mathrm{t}}+\mathrm{b}_{3} \mathrm{USR}_{\mathrm{t}-1}+\varepsilon_{\mathrm{t}} \\
& \mathrm{R}_{\text {JSEt }}=\mathrm{b}_{0}+\mathrm{b}_{1} \mathrm{R}_{\text {JSEt }-1}+\mathrm{b}_{2} \sigma_{\mathrm{t}}+\mathrm{b}_{3} \mathrm{USR}_{\mathrm{t}-1}+\varepsilon_{\mathrm{t}}
\end{aligned}
$$

Variance Equation:-

$$
\begin{array}{r}
\left.\log \left(\sigma_{t}^{2}\right)=\omega+\alpha\left[\varepsilon_{t-1}\right]-\sqrt{2}_{2}\right]+\beta_{1} \log \left(\sigma_{t}^{2}\right)+\gamma\left[\varepsilon_{t-1}\right] \\
\left.\left[\sigma_{t-1}\right]-\sqrt{\Pi}\right]
\end{array}
$$

The variance equation remains the same for all cases of equations (3) to (6), while the volatility parameters to be estimated include: $\omega, \alpha, \beta_{1}$ and $\gamma$. 
Where;

$\omega=$ Constant Coefficient of Variance equation;

$\alpha=$ Determinant of EGARCH Effects; depicting the Volatility Clustering of stock returns;

$\beta_{1}=$ Determinant of the degree of volatility persistence;

$\gamma=$ Depicts the Asymmetric and Leverage effects;

$b_{1}=$ Depicts the coefficient of lagged dependent variable; to correct for the possible presence of firstorder serial correlation or autocorrelation;

$\mathrm{b}_{2}=$ Coefficient of Expected Risk;

b3 = Depicts the coefficient of global economic crisis by way of contagion from the US.

$\mathrm{R}_{\text {AFRICAt }}=\mathrm{It}$ is the stock return of traded stocks in the African stock markets; which is the logarithmic ratio of all-share-index to its lagged value in the respective days of the years;

$\mathrm{R}_{\text {CASEt }}=$ stock return of traded stocks in the Cairo stock market; which is the logarithmic ratio of allshare-index to its lagged value in the respective days of the years;

$\mathrm{R}_{\mathrm{NSEt}}=$ stock return of traded stocks in the Nigerian stock market; which is the logarithmic ratio of all-share-index to its lagged value in the respective days of the years;

$\mathrm{R}_{\mathrm{JSEt}}=$ stock return of traded stocks in the Johannesburg stock market; which is the logarithmic ratio of all-share-index to its lagged value in the respective days of the years;

$\mathrm{USR}_{\mathrm{t}-1}=$ lagged U.S. stock returns which account for price spillover and it also captures the global factor (Dungey, Fry, Gonzalez-Hermosillo and Martin 2003);

$\mathrm{R}_{\text {AFRICAt-1, }} \mathrm{R}_{\text {CASEt-1, }} \mathrm{R}_{\text {NSEt-1, }} \mathrm{R}_{\text {JSEt-1 }}=$ the effect of past day's stock return on the current day; that is, the efficiency of the African, Cairo, Nigerian and the Johannesburg stock markets; nets off the consequential effects of global contagion. This also allows for a possible inherent autocorrelation problem in the model (Olowe, 2009).

\section{ARCH-ML TEST}

Estimations from Table 10 indicate that the coefficient of lag of stock returns $\left(b_{1}\right)$ for the holistic African model, the CAIRO, NSE and JSE are only significant for the Cairo and the Johannesburg stock market returns while those of the Nigeria and the African are insignificant at the $5 \%$ level. This confirms that the inclusion of the lagged dependent variables in correcting for autocorrelation problems are only justified for the Cairo and Johannesburg cases.

In addition, the coefficient of expected risk $\left(b_{2}\right)$ are positive and significant for the African stock markets and the Johannesburg stock markets, while those of Nigeria and Cairo are insignificant with the latter being even negatively insignificant. These suggest that direct and significant relationship exists between the stock return and its own volatility (risk) for the holistic African and Johannesburg stocks. At the same time, little evidence exists between stock return and its volatility for that of Nigerian stocks (because, since though positive it was insignificant) but an inverse relationship, though insignificant, between stock returns and its volatility appeared in the Cairo case. 
Table 10

Parameter Estimates of the E-GARCH Models during the Global Period - Holistic African Stock Markets and Individual Surrogate African Countries' Stock Markets

\begin{tabular}{|c|c|c|c|c|}
\hline Estimation & $\begin{array}{c}\text { AFRICAr } \\
\text { (Aggregate) }\end{array}$ & CASEr & JSEr & NSEr \\
\hline \multicolumn{5}{|c|}{ Mean Equation } \\
\hline $\mathrm{b}_{0}$ & $\begin{array}{c}0.0007 * \\
(0.00017)\end{array}$ & $\begin{array}{c}0.0024 \\
(0.0015)\end{array}$ & $\begin{array}{c}-0.0250 * \\
(0.0007)\end{array}$ & $\begin{array}{l}-0.2932 \\
(0.4558)\end{array}$ \\
\hline$b_{1}$ & $\begin{array}{l}-0.0027 \\
(0.0061)\end{array}$ & $\begin{array}{l}0.1351 * \\
(0.0734)\end{array}$ & $\begin{array}{l}0.0174 * \\
(0.0004)\end{array}$ & $\begin{array}{l}-0.5947 \\
(1.3741)\end{array}$ \\
\hline$b_{2}$ & $\begin{array}{l}3.3888 * \\
(0.2515)\end{array}$ & $\begin{array}{c}-8.0361 \\
(10.4234)\end{array}$ & $\begin{array}{l}0.8478 * \\
(0.4644)\end{array}$ & $\begin{array}{c}14.4479 \\
(24.0138)\end{array}$ \\
\hline$b_{3}$ & $\begin{array}{l}0.7882 * \\
(0.0181)\end{array}$ & $\begin{array}{c}0.0290 \\
(0.0734)\end{array}$ & $\begin{array}{l}0.0174 * \\
(0.0004)\end{array}$ & $\begin{array}{c}2.1046 \\
(3.6870)\end{array}$ \\
\hline \multicolumn{5}{|c|}{ Variance Equation } \\
\hline$\omega$ & $\begin{array}{c}-12.6064 * \\
(0.4202)\end{array}$ & $\begin{array}{c}-1.9455^{*} \\
(0.5841)\end{array}$ & $\begin{array}{l}-3.1977 \\
(9.8553)\end{array}$ & $\begin{array}{c}-3.9177 \\
(13.3197)\end{array}$ \\
\hline A & $\begin{array}{l}1.5920 * \\
(0.0333)\end{array}$ & $\begin{array}{l}-0.0735 \\
(0.0939)\end{array}$ & $\begin{array}{c}-1.0125 * \\
(0.6331)\end{array}$ & $\begin{array}{c}0.2678 \\
(0.3726)\end{array}$ \\
\hline $\mathrm{B}_{1}$ & $\begin{array}{c}-0.6209 * \\
(0.2298)\end{array}$ & $\begin{array}{l}0.7676 * \\
(0.0663)\end{array}$ & $\begin{array}{c}0.0095 \\
(0.3688)\end{array}$ & $\begin{array}{c}0.0131 \\
(0.6152)\end{array}$ \\
\hline$\Gamma$ & $\begin{array}{l}0.4160 * \\
(0.1111)\end{array}$ & $\begin{array}{l}0.4480 * \\
(0.2887)\end{array}$ & $\begin{array}{l}-0.6872 \\
(0.8216)\end{array}$ & $\begin{array}{c}0.1598 \\
(0.2634)\end{array}$ \\
\hline $\mathrm{b}_{1}$ & $\begin{array}{c}0.2557 \\
(0.1955)\end{array}$ & $\begin{array}{l}-47.0112 \\
(21.5499)\end{array}$ & $\begin{array}{l}-0.0186 \\
(3.3185)\end{array}$ & $\begin{array}{c}0.1889 \\
(0.6577)\end{array}$ \\
\hline $\mathrm{B}_{2}$ & $\begin{array}{c}-1.4164 * \\
(0.4464)\end{array}$ & $\begin{array}{c}-10.9431 * \\
(6.6742)\end{array}$ & $\begin{array}{c}0.0018 \\
(9.3228)\end{array}$ & $\begin{array}{c}-0.2735 \\
(12.7165)\end{array}$ \\
\hline Persistence & -0.6209 & 0.7676 & 0.0095 & 0.0131 \\
\hline AIC & -4.5234 & -6.0039 & -0.4379 & -0.9962 \\
\hline $\mathrm{SC}$ & -4.3872 & -5.8677 & -0.3017 & 0.8600 \\
\hline $\mathrm{N}$ & 262 & 262 & 262 & 262 \\
\hline
\end{tabular}

Source: E-views Output. *Significant at the $5 \%$ level.

On the other hand, the coefficient of global economic crisis $\left(b_{3}\right)$ was positively related in all cases (i.e. the holistic Africa, Cairo, Nigeria and Johannesburg stock markets), but was only significantly related to stock market returns in the holistic Africa and the Johannesburg stock markets. This implies that the global economic and financial crisis only significantly affected the holistic African markets and the Johannesburg stock markets during the crisis period. Though also affected the Cairo and Nigerian stock markets returns, it was insignificant during the crisis period. The indication from these findings is the magnificent nature of the Johannesburg stock market in the overall portion of the African stock markets' content. 
Aside from the mean equation analyses as above, the variance equations show that the sum of $\alpha$ coefficient is positive for the overall Africa, Nigeria and Johannesburg stock returns but negative for that Cairo. However, only the holistic Africa and Johannesburg stock markets returns are significant at the $10 \%$ levels. These confirm that the presences of ARCH effects are very pronounced in the African and the Johannesburg stock markets; though they are present in the Nigerian case too, they are insignificant in nature and absent completely and insignificantly in the Cairo stock market. The presences of ARCH effects denote the prevalence of volatility clustering since conditional volatility tends to rise (fall) when the absolute value of standardized residuals is larger (smaller) (Leon, 2007).

Table 9 also shows that the $\beta$ coefficient which is the determinant of the degree of persistence is statistically significant in the holistic African stock markets and the Cairo cases but insignificant for the Nigerian and the Johannesburg cases. The sum of the $\beta$ coefficients in the African, Cairo, Nigeria and Johannesburg cases are $-0.6209,0.7676,0.0131$, and 0.0095 respectively. With these coefficients for the degree of persistence, it shows that very high persistence in volatility exists since the sum of $\beta$ on the average is close to one (1) in the holistic model and closer 1 in the Cairo model but very low (closer to zero) in the Nigerian and Johannesburg cases. The high volatility shows that the holistic African stock markets and the Cairo stock markets are more volatile during the global economic and financial crisis. These findings are highly revealing as we are able to determine that the volatility in Nigerian stock market and possibly the Johannesburg during the period of global economic and financial crisis could have been more accounted for by the stock market crash than by the global economic crisis.

Therefore, this agrees with the findings in the study of Olowe (2009) which conclusively posited that the stock market crash (and/or not the global financial crisis) could have accounted for sudden changes in variance both in the Nigerian and Johannesburg stock markets, and likewise in the holistic African and Cairo stock markets. These assertions are further established by the augmented EGARCH-inMean model with the inclusion of the global economic crisis, as represented by the US stock returns in the variance equations of all models. The volatility persistence is higher and significant in the Africa and Cairo stock market returns but lower and insignificant in the Nigeria and Johannesburg cases, thus, corroborating the above assertions.

Furthermore, Table 9 also indicates that the asymmetric and leverage effects are negatively insignificantly for the Johannesburg model, positive for the holistic Africa, Cairo and the Nigerian models but significant for the African stock markets (at the 5\% level) and the Cairo stock markets at the $10 \%$ level. The presence of the negative and insignificant asymmetric and leverage effects show that the asymmetric and leverage effects are accepted for the African and Cairo models but rejected for the Nigeria and Johannesburg models.

The coefficients from the estimates in Table 11 are to ascertain the diagnostic fitness of the models specified for prediction and their appropriateness for forecasting. As evidenced, the coefficients for the autocorrelation standard residuals and the autocorrelation standard square residuals are insignificant (since probability values are closer to 1) for the aggregate African model, the Cairo model and the Johannesburg model. These signify that there are absences of serial correlation in both the mean and variance equations as specified in the models above (see equations 3-7); therefore the models are appropriately specified and there are absences of additional ARCH effects in the variance equations of the respective model. 
Table 11

Autocorrelation of Standard Residuals, Autocorrelation of Square Standard Residuals and ARCH LM Test of the Order 4 for the EGARCH-in-Mean over the Global Crisis Period

\begin{tabular}{lcccc}
\hline Estimation & AFRICAr & CASEr & JSEr & NSEr \\
\hline Ljung-Box Q-stat & & & & \\
\hline Q(1) & 0.0040 & 0.1889 & 0.0528 & 1.4497 \\
& $(0.950)$ & $(0.664)$ & $(0.8180)$ & $(0.2290)$ \\
Q(2) & 0.0079 & 2.0208 & 0.0607 & 1.5836 \\
& $(0.996)$ & $(0.364)$ & $(0.9700)$ & $(0.4530)$ \\
Q(3) & 0.012 & 2.0342 & 0.0825 & 4.7417 \\
& $(1.000)$ & $(0.565)$ & $(0.9940)$ & $(0.1920)$ \\
Q(4) & 0.0160 & 2.0608 & 0.5519 & 4.7583 \\
& $(1.000)$ & $(0.725)$ & $(0.9680)$ & $(0.3130)$ \\
\hline Ljung-Box Squared & AFRICAr & CASEr & JSEr & NSEr \\
\hline \multirow{2}{*}{ Q-stat } & $($ Holistic) & 0.1800 & 0.0090 & 0.0030 \\
& 0.0039 & $(0.6710)$ & $(0.9250)$ & $(0.986)$ \\
Q(2) & $(0.950)$ & 1.0341 & 0.0240 & 0.0111 \\
& 0.0079 & $(0.5960)$ & $(0.9880)$ & $(0.9940)$ \\
Q(3) & $(0.996)$ & 1.3469 & 0.0395 & 0.0510 \\
& 0.0119 & $(0.7180)$ & $(0.9980)$ & $(0.9970)$ \\
Q(4) & $(1.000)$ & 1.3597 & 0.0440 & 0.0687 \\
& 0.0160 & $(0.851)$ & $(1.000)$ & $(0.9990)$ \\
ARCH LM Test & $(1.000)$ & 0.1764 & 0.0088 & 0.0003 \\
N*R & 0.0038 & $(0.6749)$ & $(0.9254)$ & $(0.9859)$ \\
\hline & $(0.9507)$ & 0.1776 & 0.0088 & 0.0003 \\
& 0.0039 & $(0.6734)$ & $(0.9251)$ & $(0.9858)$ \\
\hline
\end{tabular}

Source: E-views Output. p values are in paranteses.

\section{CONCLUSION AND POLICY RECOMMENDATIONS}

This study which has the primary aim of investigating the relationship between the global economic crisis and the stock market efficiency in selected African countries comes up with the conclusion that the major driver of the African stock markets is the Johannesburg stock market since the consequential effect of the global economic crisis on this stock market subjected the overall (holistic) African stock markets to significant effects, even to the extent that the cumulative strengths of the other surrogate countries of Nigeria and Cairo could not stop the intensity. This assertion is further confirmed by the volatility clustering that is more manifest in the Johannesburg stock market and by extension to the holistic African stock markets. It is the only market that can be considered efficient.

However, the degree of persistence of volatility is high in the holistic Africa and Cairo stock markets; implying that the volatility clustering is short-lived in the Johannesburg and Nigeria stock markets during the global economic crisis, but has a more overarching effect in the Cairo stock market. 
Also, it could be adduced from the study that the Cairo stock market betrays the very conscience of simple finance theory that higher return is usually accorded with higher risk since its stock return is negatively linked with its risk (volatility) while those of the holistic Africa and Johannesburgs re-affirm the risk-return nexus as both relationships are positively significant. The Nigerian case is insignificant, though positive. Overall, the stock markets in Africa react slowly and with some long lag to the global crisis.

The findings evidenced in the use of the EGARCH technique are highly supported by the findings in the Augmented Dickney Fuller (ADF) and the Phillip-Perron tests of Unit Root.

On the whole, the models are found to be free of specification biases as substantiated by the insignificance p-values in the diagnostic tests of Ljung Q-tests and Ljung $\mathrm{Q}^{2}$-tests for the mean and variance equations respectively.

The following policy recommendations are considered germane:

i. There is need for sound macroeconomic policies that will assist the developmental process of the stock markets in the African continent. This is necessary in view of the gradual exposure of the stock markets to global financial activities.

ii. Regional integration involving harmonization of stock market procedure and practices should be encouraged in the continent as this will solidify the continent in some particular area of interest such as the stock markets. This creates a kind of network for the stock markets in the African continent and therefore results in a synergetic arrangement where individual strengths of member countries are coordinated and weaknesses are alleviated.

iii. Under (ii) above, there should be cross-fertilisation of ideas among operators in the stock markets through workshops, symposia and deliberate inter-regional economic community networking.

\section{REFERENCES}

Abraham, H.W. (2010). "The Impact of the Global Economic and Financial Crisis on Selected Stock Markets in Africa: Evidence from AEG-ADL Estimations." A paper submitted for consideration to the African Economic Research Consortium (AERC) for presentation at the Rethinking African Economic Policy in Light of the Global Economic and Financial Crisis Conference.

African Development Bank, (2009). The Impact of the Global Economic Crisis on Africa. A Publication of the African Development Bank (ADB) and African Development Fund (ADF), February.

Allen, F. and Gale, D. (2007). Understanding Financial Crises. New York: Oxford University Press.

Bailey, R.E. (2005). The Economics of Financial Markets. Cambridge.

Baillie, R.T. and DeGennarro, R.P. (1990). "Stock Returns and Volatility," Journal of Financial and Quantitative Analysis, 25 203-214.. 
Bank of England, (2007). "Shocks to the Financial System," Financial Stability Report 22 (October): 16-28. Available [online] at: http://www.bankofengland.co.uk/publication/fsr/2008/fsrfull0804.pdf.

Beaver, W.H. (1981): “Market Efficiency,” Accounting Review, 56: 23-37.

Bollerslev, T. (1986). “Generalized Autoregressive Conditional Hetroscedasticity,” Journal of Econometrics, 31: 307-327.

Brambila, M.J; and Massa, I. (2009). "The Global Financial Crisis and sub-Saharan Africa: The Effects of Slowing Private Capital Inflows on Growth," ODI Working Paper 304. London: Overseas Development Institute.

Chang, R. and Valesco, A. (1998). "Financial Crises in Emerging Markets," NBER Working Paper, No. 6606.

Chou, R.Y. (1988). "Volatility Persistence and Stock Valuations: Some Empirical Evidence Using GARCH," Journal of Applied Economics, 3: 279-294.

Choudhury, S.K. (1991). "Short-Run Share Price Behavior: New Evidence on Weak Form of the Market Efficiency," Vikalpa, 16(4): 17-21.

Chung, H.Y. (2006). "Testing Weak Form Efficiency of the Chinese Stock Market,” Karhula, China. Department of Business Administration. Lappeeranta University of Technology,

Coleman, C. (2008). “The Impact of the Global Financial Crisis on Africa,” Speech delivered by Colin Coleman, Managing Director - Goldman Sachs International to Commonwealth Business Council's African Investment Forum Gallagher Estate, $19^{\text {th }}$ November, 2008.

Collins, D. and Biekpe, N. (2004). "Contagion: A Fear for African Equity Markets," in S. Mensah and T. Mosss (eds.), African Emerging Markets, Contemporary Issues, 11:198-209.

Corsetti, G; Pesenti, P., and Roubini, N. (1999). "Paper Tigers? A Model of the Asian Crisis," European Economic Review, 43: 1211-1236.

Didier, T., Paolo, M., and Schmukler, S.L. (2008). "Vanishing Financial Contagion," Journal of Policy Modeling, 3(5): 775-791.

Ding, Z., Engle R.F., and Granger, C.W.J. (1993). "Long Memory Properties of Stock Market Returns and a New Model," Journal of Empirical Finance, 1. 83-106.

Dongey, M., Fry, R., Gonzalez-Hermosillo, B., and Martin, V. (2003). "Unanticipated Shocks and Systemic Influences: The Impact of Contagion in Global Equity Markets in 1998," IMF Working Paper 03/84, International Monetary Fund. 
Edwards, S. (2000). "Contagion," University of California, Los Angeles and National Bureau of Economic Research. Revised Version of the 1999 World Economy Lecture delivered at University of Nottingham.

Engle, R.F. (1982). "Autoregressive Conditional Heteroscedasticity with Estimates of the Variance of United Kingdom Inflation," Econometrica, 50(4): 987-1008.

Engle, R.F., Lilien, D.M., and Robins, R.P. (1987). "Estimating Time Varying Risk Premia in the Term Structure: The ARCH-M Model," Econometrica, 55. 391-407.

European Central Bank, (2007). "The Macro-Financial Environment," Financial Stability Review, (December): 19-79. Available [online] at:

http://www.ecb.int/pub/pdf/other.financialstabilityreview200712en.pdf

Fama, E.F. (1970). "Efficient Capital Markets: A Review of Theory and Empirical Work," The Journal of Finance, 25(2): 383-417.

Flood, R. and Garber, P. (1984). "Collapsing Exchange Rate Regimes: Some Linear Example," Journal of International Economics, 17: 1-13.

Flood, R., Garber, P., and Kramer, C. (1996). "Collapsing Exchange Rate Regimes: Another Linear Example," Journal of International Economics, 41(3-4): 223-234.

Flood, R. and Marion, N. (1996). "Speculative Attacks: Fundamentals and Self-fulfilling Prophecies, " NBER Working Paper, No. 57-89.

French, K.R., Schwert, G.W., and Stambaugh, R.E. (1987). "Expected Stock Returns and Volatility," Journal of Financial Economics, 19: 3-29.

Fundanga, C.M. (2009). "The Effects of the Crisis on Africa," Remarks by Dr. Caleb M. Fundanga, Governor of the Bank of Zambia at the AERC Senior Policy Seminar (SPSXI), Lusaka, 6 April.

Glosten, L.R., Jagannathan, R., and Runkle, D. (1993). "On the Relation between the Expected Value and the Volatility of the Nominal Excess Return on Stocks," Journal of Finance, 48: 1779-1801.

Grossmann, S.J. and Stiglitz, J.E. (1980). "On the Impossibility of Informationally Efficient Market," Journal of Finance, 31: 573-538.

Gupta, O.P. (1985). "Behavior of Share Prices in India: A Test of Market Efficiency,".National Journal of Business, New Delhi.

Gupta, R. and Basu, P.K. (2007). "Weak Form Efficiency in India Stock Markets," IBER Journal, 6(3): 57-64.

Inanga, I.L. and Emenuga, C. (1997). "Institutional, Traditional and Asset Pricing Characteristics of the NSE," African Economic Research Consortium (AERC) Paper 60 March. 
International Monetary Fund (IMF), (2009). The Implications of the Global Financial Crisis for LowIncome Countries. A publication of the IMF (March).

Jensen, M.C. (1978): “Some Anomalous Evidence Regarding Market Efficiency,” Journal of Financial Economics, 6: 95-101.

Karolyi, G.A. (2001). "Why Stock Return Volatility Really Matters," Papers Prepared for Inaugural Issue of Strategic Investor Relations, Institutional Investor Journals Series, February.

Kasekende; A. (2008). "The Global Financial Crisis: Impacts on Growth and Development in African Countries". Presentation to INWENT.

Krugman, P. (1979). “A Model of Balance of Payment Crises," Journal of Money, Credit and Banking, 11: 311-325.

Kulkani, N.S. (1978). "Share Price Behavior in India: A Spectral Analysis of Random Walk Hypothesis," The India Journal of Statistics, Sankhya, 40: 135-162.

Latham, M. (1986). "Informational Efficiency and Information Subsets". Journal of Finance, 41: 3952.

Léon, N.K. (2007). "Stock Market Returns and Volatility in the BRVM," African Journal of Business Management, 15:107-112.

Leroy, S.F. (1989). "Efficient Capital Markets and Martingales," Journal of Economic Literature, 27(4): 1583-1621.

Malkiel, B.G. (2003): “The Efficient Market Hypothesis and Its Critics,” Journal of Economic Perspectives, 71(1): 59-82.

Mishra, P.K. (2009). “India Capital Market - Revisiting Market Efficiency,” India Journal of Capital Markets, 2(5): 30-34.

Mishrah, P.K. and Pradhan, B.B. (2009). "Capital Market Efficiency and Financial Innovation - A Perspective Analysis," The Research Network, 4(1): 1-5.

Nelson, D.B. (1991). "Conditional Heteroskedasticity in Asset Returns: A New Approach," Econometrica, 59: 347 - 370 .

Ngo-Mambongo, A. and Lawal, Z. (2008). "Financial Development in African Countries," A paper presented at the Andrew Young School of Public Policy, Georgia State University.

Obadan, M.I. (1998). “Capital Market and Nigeria's Economic Development," Presidential Address presented during a One day Seminar organized by Nigerian Economic Society at the Institute of International Affairs, Lagos, 21st January. 
Obstfeld, M. (1986). "Rational and Self-Fulfilling Balance of Payment Crises," American Economic Review, 76(March): 72-81.

------, (1994). “The Logic of Currency Crises,” Cahiers Economiques et Monetaires, Bank of France, 43: 189-213.

Olowe, R.A. (2009). "Stock Return, Volatility and the Global Financial Crisis in Emerging Market: The Nigerian Case," International Review of Business Research Papers, 5(4)): 426-447.

Pandey, A. (2003). “Efficiency of India Stock Market,” A Part of Project Report, IGIDR, Mumbai.

Pant, B; and Bishnoi, T.R. (2002). "Testing Random Walk Hypothesis for Indian Stock Market," Working Paper Series, IIM, Ahmadabab, Indies.

Pesaran, M.H. (2005): "Market Efficiency Today," IEPR Working Paper. Available [online] at: http://www.usc.edu.iepr

Poshakwale, S. (1996). "Evidence on Weak Form Efficiency and Day of the Week Effect in the Indian Stock Market," Finance India, 10(3): 605-616.

Pristy, S. (2007). "Market Efficiency and Financial Markets Integration in India," India Journal of Economics and Business, 5(3): 114-121.

Ramachadran, J. (1985). "Behavior of Stock Market Prices, Trading Rules, Information and Market Efficiency.” Doctoral Dissertation, India Institute of Management, Ahmadabad.

Sebnet, W.L. and Ochere, I. (2008). African Stock Markets. IMF Institute.

Sharma, J.L. (1983). "Efficiency Capital Market and Random Character of Stock Prices Behavior in a Developing Economy," India Journal of Economics, 3: 251-395.

Schwert, W. (1989). “Stock Volatility and Crash of '87'," Review of Financial Studies, 3: 77-102.

Soludo, C.C. (2009). Global Financial and Economic Crisis: How Vulnerable is Nigeria? A publication of the CBN, January.

Srinivasan, N.P. and Narasimhan, M.S. (1998). “Testing Stock Market Efficiency Using Risk-Return Parity Rule," Vikalpa, 13: 61-66.

Stevens, G. (2008), "Economic Prospects in 2008: An Antipodean View,” Address by the Governor of the Reserve Bank of Australian to Australian Business, January 18, London, UK.

Taylor, S. (1986). Modeling Financial Time Series. Great Britain: John Wiley \& Sons. 
Tella, S.A. (2009). "Global Financial Contagion,” A paper presented at the Workshop on Global Financial Meltdown and the Nigerian Banking and Finance Sector Organized by the Centre for Policy and Economic Research at the Chelsea Hotel, Abuja.

Te Velde et al., (2009). “The Global Financial Crisis and Developing Countries.” A Preliminary Synthesis of Ten Draft Country Reports Funded by the Overseas Development Institute (ODI) and the UK Development for International Development (April).

Te Velde, D.W. (2008). “The Global Financial Crisis and Developing Countries.” A paper published by Overseas Development Institute.

Timmermann, A., and Granger, C.W.J. (2004): "Efficient Market Hypothesis and Forecasting," International Journal of Forecasting, 20: 15-27.

UNESCECA and AUC, (2009). "The Global Financial Crisis: Impact, Responses and Way Forward.” United Nations Economic and Social Council Economic Commission for Africa (UNESCECA) and African Union Commission (AUC): Twenty-eight Meeting of the Committee of Experts, Cairo, Egypt, 2-5 June 2009.

Vaidyanathan, R; and Gali, K.K. (1994). "Efficiency of the India Capital Market," India Journal of Finance and Research, 5(2): 24-31

WDI (2004). "World Development Indicator."

------, (2009). “World Development Indicator.”

Zakoïan, J.M. (1994). “Threshold Heteroskedastic Models," Journal of Economic Dynamics and Control, 18: 931-944. 